\title{
LITHIUM BIOSORPTION BY Arthrospira (Spirulina) PLATENSIS BIOMASS
}

\begin{abstract}
The biosorption of lithium from batch systems by Arthrospira (Spirulina) platensis biomass was studied. Adsorption capacity of the biosorbent was investigated as a function of contact time, initial metals concentration and $\mathrm{pH}$ values. Lithium content in biomass was determined using Proton Induced Gamma Emission technique. The ability of spirulina biomass for lithium biosorption showed a maximum at the $\mathrm{pH}=11$. Equilibrium data fitted well with the Langmuir model with maximum adsorption capacity of $1.75 \mathrm{mg} / \mathrm{g}$, while the kinetic data were best described using the pseudo second-order kinetic model. The IR spectrum of the Li-loaded biomass revealed that lithium ions could be primarily bind to $-\mathrm{OH},-\mathrm{COOH},-\mathrm{NH},-\mathrm{NH}_{2}$, and $-\mathrm{NH}_{3}$ groups present on biosorbent surface. Arthrospira platensis biomass could be applied as environmentally friendly sorbent for lithium removal from wastewater.
\end{abstract}

Keywords: biosorption, lithium, Arthrospira platensis, PIGE technique, FT-IR spectroscopy

\section{Introduction}

Nowadays, the demand for lithium has been increasing dramatically due to its wide application as raw material for large-capacity rechargeable batteries, light aircraft alloys, and future nuclear fusion fuel [1]. It is also applied for production of heat-resistant ceramics, and pharmaceuticals [2]. Lithium batteries are and will also continue to be in demand for powering all electric and hybrid vehicles. Increase use of lithium batteries doubtless will lead to formation of large amount of solid waste, containing lithium amount with other heavy metals [3]. Lithium is now recovered from mines and salt lakes, which contain about $17 \mathrm{Tg}$ (million tonnes) of lithium in total [4].

For lithium removal from solutions are used several traditional techniques such as solvent extraction, ion-exchange, precipitation, membrane processes, and adsorption $[1,2]$. However, industrial scale use of ion-exchange resins is limited due to use of toxic chemical that may lead to secondary environment pollution [2]. The conventional techniques for treatment and recycling of metal-bearing wastes, mainly pyro-metallurgy, hydrometallurgy or combination both of them requires high capital investment and can lead to second pollution as well.

\footnotetext{
${ }^{1}$ Joint Institute for Nuclear Research, 6 Joliot-Curie Str., 1419890, Dubna, Russia

${ }^{2}$ Horia Hulubei National Institute for R\&D in Physics and Nuclear Engineering, 30 Reactorului Str. MG-6, Bucharest - Magurele, Romania

${ }^{3}$ Department of Environmental Management, Faculty of Management, University of Prešov, Konštantínova 16, 08001 Prešov, Slovak Republic

*Corresponding author: zinikovskaia@mail.ru
} 
In this case, interest for lithium removal and bioleaching represents biological methods, are considered as one of the most promising and fast developing technologies. Literature search show just several example of microorganism use for lithium recovery. Tsuruta [2] tested 70 strains of microorganisms for their ability to accumulate lithium. Certain gram-positive bacteria were found to have an extremely high ability to accumulate lithium, particularly Arthrobacter nicotianae, which can accumulate about $126 \mu \mathrm{mol} \mathrm{Li} / \mathrm{g}$ (d.wt.). Marcincakova et al. [3] used consortia of acidophilic bacteria of Acidithiobacillus ferrooxidans and Acidithiobacillus thiooxidans for lithium bioleaching from spent lithium-ion batteries two different media. In the rich nutrient medium the overall lithium bioleaching efficiency was $80 \%$, whereas in the low nutrient environment only $35 \%$. Kurmiawan and Yamamoto [5] demonstrated applicability of biofilm matrices of natural microbial consortiums collected from Lake Biwa, Japan for lithium accumulation.

Cyanobacteria is a group of microorganisms which are widely used in removal of metal ions such from batch solution as well as and industrial effluents [6-14].

The aim of the present study was to examine the efficiency of Arthrospira (Spirulina) platensis biomass as a biosorbent for removal of lithium ions from batch solution using Proton Induced Gamma Emission (PIGE) technique. Equilibrium and kinetic studies were performed to describe the adsorption process. Functional groups responsible for metal binding were determined by Fourier transform infrared spectroscopy.

\section{Experimental}

\section{Reagents and materials}

All the chemicals used for biosorption experiments were purchased from Sigma-Aldrich and were of analytical grade.

\section{Biosorbent}

Arthrospira platensis (A. platensis) biomass purchased from "Biosolar MSU" company (Moscow, Russia) was dried in an oven at $80{ }^{\circ} \mathrm{C}$ for $24 \mathrm{~h}$. Then the biomass was homogenized in a homogenizer at $600 \mathrm{rpm}$ for $10 \mathrm{~min}$ and afterwards used in the experiments.

\section{Batch experiments}

The experiments were conducted in $100 \mathrm{~cm}^{3}$ Erlenmeyer flasks containing $50 \mathrm{~cm}^{3}$ of lithium synthetic solutions. The flasks were shaken on a shaker incubator at a constant rate of $120 \mathrm{rpm}$. To investigate the effect of $\mathrm{pH}$, initial metal concentration and contact time, different $\mathrm{pH}$ (2-11), initial metal concentrations $\left(10-100 \mathrm{mg} / \mathrm{dm}^{3}\right)$, time $(5,15,30,45 \mathrm{~min})$ were used. After experiment biomass was removed by filtration, dried till the constant weight and used for further analysis.

The experiments were carried out in triplicate $(n=3)$ to enhance reproducibility and the mean of the quantitative results were used for further calculations. The value of standard deviation for a sample was not more than $5 \%$.

\section{Methods}

Proton Induced Gamma Emission (PIGE) technique was used for a quantitative biosorbent analysis. 


\section{Sample preparation for PIGE}

Dry powder samples were ground in agate mortar, then prepared as pellets (thick targets) of $1 \mathrm{~cm}$ diameter and $1 \mathrm{~mm}$ thickness using hydraulic press. As comparator standards for lithium determination, $\mathrm{LiNH}_{2}$ powder was similarly prepared as pellets (relative standardization).

\section{Experimental set-up for PIGE}

PIGE experiments were performed in a dedicated to Ion Beam analysis (IBA) reaction chamber at the $3 \mathrm{MV}$ Tandetron of IFIN-HH in Bucharest-Magurele, Romania, using a $3 \mathrm{MeV}$ proton beam normal to the target support (Fig. 2b), in vacuum (beam diameter on target of about $2 \mathrm{~mm}$ ) [15]. Characteristic gamma-rays from ${ }^{7} \mathrm{Li}\left(\mathrm{p}, \mathrm{p}^{\prime} \gamma\right)^{7} \mathrm{Li}$ and ${ }^{7} \mathrm{Li}(\mathrm{p}, \mathrm{n} \gamma)^{7} \mathrm{Be}$ nuclear reactions (477.6 and $429.1 \mathrm{keV}$, respectively) were measured using a spectrometric chain with GEM10P4-70 High Purity Germanium (HPGe) detector $\left(1.75 \mathrm{keV}\right.$ energy resolution at $1.33 \mathrm{keV}$ of ${ }^{60} \mathrm{Co}$ ), oriented at $45^{\circ}$ with respect to the target and beam direction. Beam charge on target of $22-30 \mu \mathrm{C}$ and counting time around $3000 \mathrm{~s}$ were employed. An example of PIGE spectrum of Li-loaded biomass is shown in Figure 1.

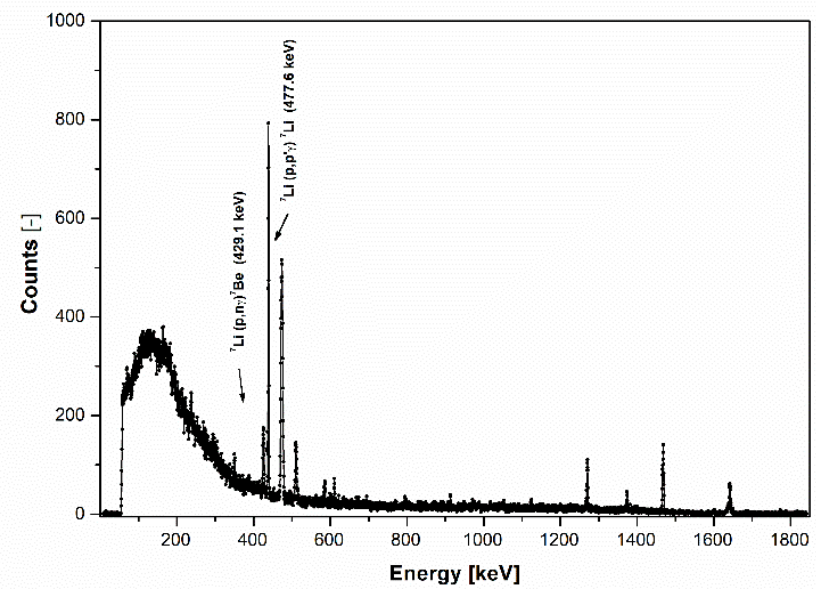

Fig. 1. Typical PIGE spectrum of Li-loaded Arthrospira platensis biomass $\left(E_{\mathrm{p}}=3 \mathrm{MeV}, t_{\mathrm{c}}=2700 \mathrm{~s}\right.$, $Q=21.71 \mu \mathrm{C})$

Quality assurance. To provide quality control of PIGE results, high purity chemical compound $\mathrm{LiNH}_{2}$ were used for PIGE calibration and/or quantitative standardization. The difference between certified and measured content of elements of the certified material varied between 3 and $7 \%$.

Fourier-transform infrared spectroscopy was used to confirm the presence of the functional groups in the samples of A. platensis and to observe the chemical modification after nickel biosorption. Infrared spectra were recorded in the range of 4,000-400 $\mathrm{cm}^{-1}$ using a Bruker Alpha Platinum-ATR spectrometer (Bruker Optics, Ettingen, Germany). 


\section{Results and discussion}

\section{Effect of pH on biosorption}

The initial $\mathrm{pH}$ value of adsorption solution is an important factor, which must be considered during sorption studies [4]. In present study, the effect of $\mathrm{pH}$ was studied at $\mathrm{pH}$ range 2-11. Obtained data are presented in Figure 2. As it can be seen from Figure 2 increase of $\mathrm{pH}$ value lead to the increase of biomass sorption capacity. The lithium sorption reached the maximum $(493 \mu \mathrm{g} / \mathrm{g})$ at $\mathrm{pH} 11$. Obtained results are confirmed by Park et al. [16], who studied the effect of $\mathrm{pH}$ in the range 2-12 on lithium sorption on $\lambda-\mathrm{MnO}_{2}$ adsorbents and showed the continuous increases of lithium biosorption with $\mathrm{pH}$ increases. Wang et al. [4] showed that uptake of $\mathrm{Li}^{+}$by ion-sieve was favourable at $\mathrm{pH}$ values $10-12$. Even in our previous studies, it was shown that optimal $\mathrm{pH}$ range for metal cationic species sorption is 4.0-6.0 [10,11, 17], in case of lithium sorption was more favourable at high $\mathrm{pH}$ values.

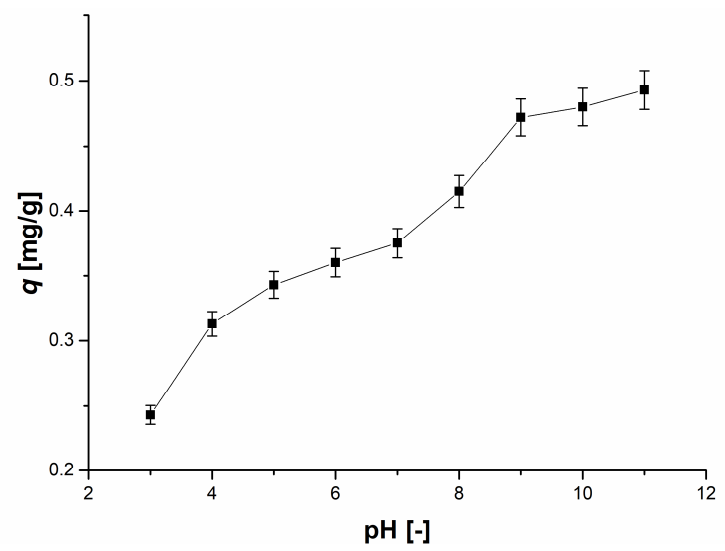

Fig. 2. Removal of lithium ions at different initial $\mathrm{pH}$ (at $T=20{ }^{\circ} \mathrm{C} ; C_{i}=10 \mathrm{mg} / \mathrm{dm}^{3}$; sorbent dosage $10 \mathrm{~g} / \mathrm{dm}^{3}$; adsorption time $2 \mathrm{~h}$ )

Wang et al. [4] concluded that lithium uptake should be carried out in stronger basic solution or rather in basic buffer solution. Authors suggested that in neutral or weak alkaline solutions due to ion-exchange reaction between $\mathrm{Li}^{+}$and $\mathrm{H}^{+}$the solution $\mathrm{pH}$ could be changed to acid zone. At low $\mathrm{pH}$ values completion of protons and lithium ions may take place that will result in incomplete lithium removal. To support Wang et al. [4] suggestion the $\mathrm{pH}$ of the sorbent-sorbate solution was measured at the beginning of the experiment and after two hours. For example, in case than initial $\mathrm{pH}$ value was 11 after two hours experiment it became 5.6. In Tsuruta [2] study it was found that lithium accumulation by the microorganisms was maximum at $\mathrm{pH}=5.8$.

\section{Effect of time and kinetics of sorption}

The evolution of the uptake data of lithium as function of time is illustrated in Figure 3. A rapid increase of lithium sorption in the first $45 \mathrm{~min}$ of interaction was observed after that the equilibrium was reached. During $30 \mathrm{~min} 90 \%$ of lithium was removed from solution by spirulina biomass. In first $5 \mathrm{~min}$ of interaction lithium content in biomass 
increases by $53 \%$ (in control biomass lithium was not detected). Tsuruta [2] have showed that maximum amount of lithium was accumulated by the A. nicotianae cells rapidly increased in the first 5 min of biomass-solution interaction. Kurmiawan and Yamamoto [5] demonstrated that maximum amount of lithium was sorbed by biofilm matrix after 1-min biosorption.

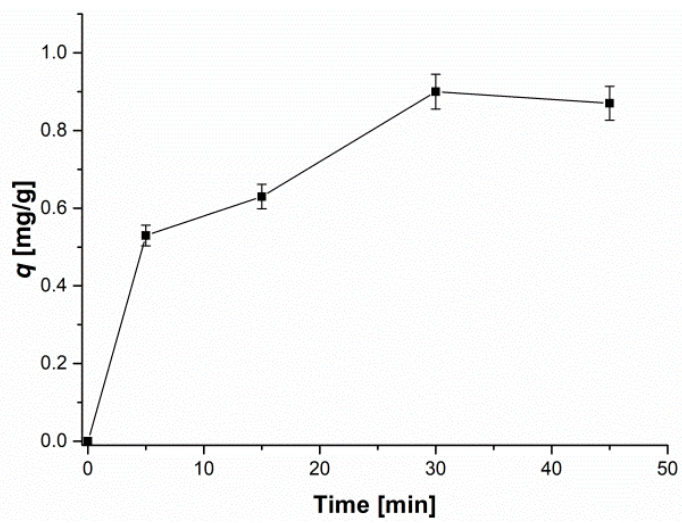

Fig. 3. Effect of contact time on the sorption of nickel ions by A. platensis biomass (at $T=20{ }^{\circ} \mathrm{C}$; $C_{i}=10 \mathrm{mg} / \mathrm{dm}^{3} ; \mathrm{pH}=11 ;$ sorbent dosage $10 \mathrm{~g} / \mathrm{dm}^{3}$ )

Lagergren's pseudo-first order and pseudo-second order models of Ho and McKay [18] were used to fit the experimental data.

Lagergren's pseudo-first order model is expressed as follows:

$$
\log \left(q_{e}-q\right)=\log q_{e}-\frac{K_{a}}{2.303} t
$$

where $q$ and $q_{e}$ are the adsorbed amounts $[\mathrm{mg} / \mathrm{g}$ ] at time $t$ [min] and at equilibrium time, respectively, $K_{a}\left[\mathrm{~min}^{-1}\right]$ is the rate constant of the first order biosorption.

Pseudo-second order model of Ho and McKay:

$$
\frac{t}{q}=\frac{1}{K_{b} q_{e}^{2}}+\frac{t}{q_{e}}
$$

where $q$ and $q_{e}$ are the adsorbed amounts $[\mu \mathrm{g} / \mathrm{g}]$ at time $t$ [min] and at equilibrium time, respectively, $K_{b}[\mathrm{~g} /(\mathrm{mg} \cdot \mathrm{min})]$ is the rate constant of the second-order biosorption.

Pseudo-first order model was not applicable to describe experimental data, correlation coefficient was 0.97 (data not shown). The pseudo-second order biosorption rate constant, $K_{b}$ and $q_{e}$ values were determined from the slope and intercept of the plot of $t / q_{t}$ against time, $t$ (Fig. 4) and obtained parameters are presented in Table 1. Fitted pseudo-second order model kinetic parameters for the removal of lithium ions by spirulina biomass are presented in Table 1. The pseudo-second order model, based on the assumption that the rate-limiting step is chemical sorption involving valency forces through sharing or exchange of electrons between sorbent and sorbate [19, 20]. 


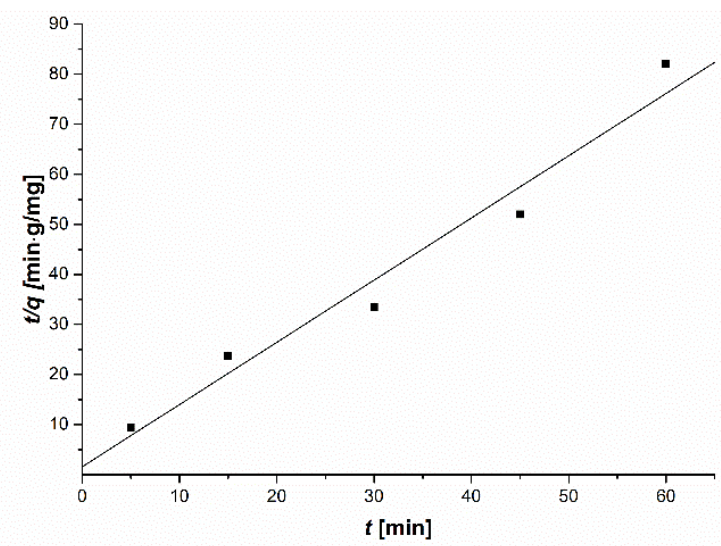

Fig. 4. The pseudo-second order plot of kinetic study of lithium biosorption on A. platensis

The pseudo-second order model parameters

\begin{tabular}{|c|c|c|c|c|}
\hline \multicolumn{5}{|c|}{ Pseudo-second order } \\
\hline$C_{e}\left[\mathrm{mg} / \mathrm{dm}^{3}\right]$ & $q_{e(\exp )}[\mathrm{mg} / \mathrm{g}]$ & $q_{e(\text { cal })}[\mathrm{mg} / \mathrm{g}]$ & $K_{b}[\mathrm{~g} /(\mathrm{mg} \cdot \mathrm{min})]$ & $R^{2}[-]$ \\
\hline 10 & 0.87 & 0.9 & 1.97 & 0.99 \\
\hline
\end{tabular}

\section{Effect of concentration and isotherm modelling}

Increase of metal concentration in solution was in direct ration with its uptake by biomass. The maximum achieved adsorption capacity was $1.3 \mathrm{mg} \mathrm{Li} / \mathrm{g}$ of biomass.

Two models: Langmuir and Freundlich were used to describe the experimental data:

The Langmuir model expressed as:

$$
\frac{1}{q_{e}}=\frac{1}{q_{\max }}+\frac{1}{b q_{\max } C_{e}}
$$

where $q_{e}$ is the amount of metal adsorbed per unit weight of adsorbent at equilibrium $[\mathrm{mg} / \mathrm{g}], q_{\max }$ is the maximum metal uptake per unit mass of the adsorbent $(\mathrm{mg} / \mathrm{g}], b$ is the Langmuir constant $\left[\mathrm{dm}^{3} / \mathrm{mg}\right]$, related to the energy of sorption, which quantitatively reflects the affinity between the sorbent and the sorbate and $C_{e}$ is the equilibrium concentration of adsorbate $\left[\mathrm{mg} / \mathrm{dm}^{3}\right]$.

The general Freundlich equation is written as follows:

$$
\ln q_{e}=\ln K_{F}+\frac{1}{n} \ln C_{e}
$$

where $K_{F}$ and $1 / n$ are Freundlich constants, associated with adsorption capacity and adsorption intensity, respectively.

The isotherm parameters have been calculated from linearized plots corresponding to each isotherm model (Fig. 5) and are summarized in Table 2. 

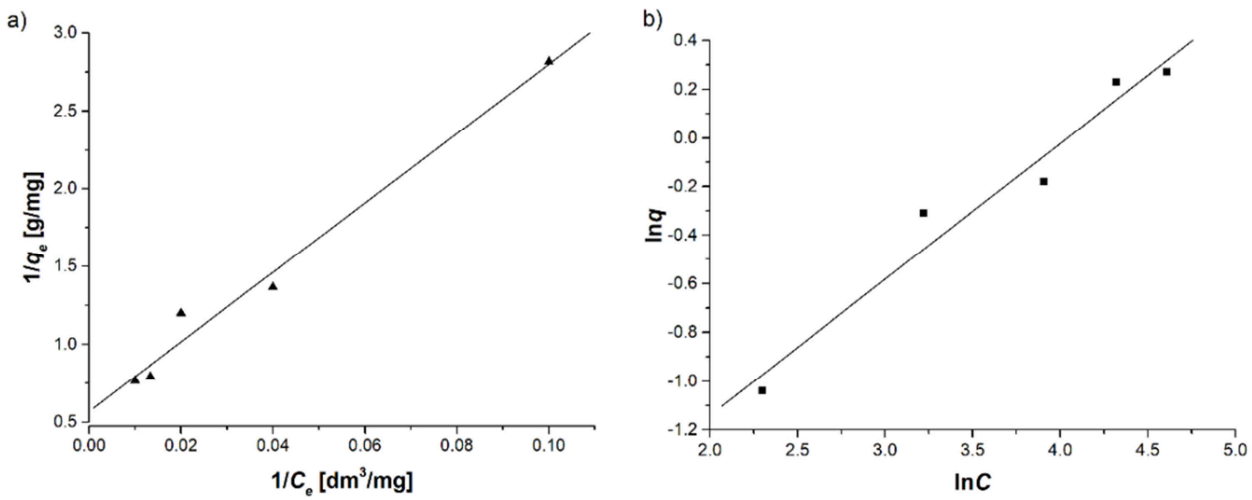

Fig. 5. a) Langmuir and b) Freundlich isotherm models for dry biomass

Isotherm parameters for the biosorption of lithium ions on A. platensis biomass

\begin{tabular}{|c|c|c|c|}
\hline \multicolumn{2}{|c|}{ Langmuir model } & \multicolumn{2}{c|}{ Freundlich model } \\
\hline$R^{2}[-]$ & 0.99 & $R^{2}[-]$ & 0.97 \\
\hline$q_{\max }[\mathrm{mg} / \mathrm{g}]$ & 1.75 & $K_{F}[\mathrm{mg} / \mathrm{g}]$ & 0.1 \\
\hline$b\left[\mathrm{dm}^{3} / \mathrm{mg}\right]$ & 0.015 & $n[-]$ & 1.78 \\
\hline
\end{tabular}

A basic assumption of the Langmuir theory is that sorption takes place at specific homogeneous sites within the sorbent. It is suggested that once a metal ion occupies a site, no further sorption can take place at that site [20]. The value of correlation experiment indicate that sorption data follows the Langmuir sorption isotherm. Correlation coefficient for Freundlich model was lower than that obtained for Langmuir model. Experimentally obtained maximum $q$ value was comparable to the maximum adsorption obtained from the Langmuir isotherm. This suggest that lithium is adsorbed in the form of monolayer coverage on the surface of the prepared adsorbent [21].

\section{Mechanisms of lithium biosorption}

The mechanism of metal biosorption includes adsorption on surface, binding to functional groups, diffusion through pores and ion exchange [22]. In order to confirm participation of the functional groups in lithium biosorption the biomass was analysed by FTIR spectroscopy. Spectrum of control biomass shows several major intense bands, around wavenumbers 3,$282 ; 2,926 ; 1,634 ; 1,538 ; 1,454 ; 1,392$; and $1,056 \mathrm{~cm}^{-1}$ (Fig. 6). The strong boarded peak at wavenumber $3,282 \mathrm{~cm}^{-1}$ could be attributed to hydroxyl $(-\mathrm{OH})$ and amine $(-\mathrm{NH})$ functional groups [22-24]. The presence of methyl $(-\mathrm{CH})$ stretching vibrations could be confirmed by the adsorption peak at wavenumber $2,926 \mathrm{~cm}^{-1}$ [24]. The adsorption peaks in the region at wavenumbers $1,750-1,300 \mathrm{~cm}^{-1}$ could be assigned to $-\mathrm{CO}$ stretches of aldehydes, ketones, and carboxylate [22, 23]. In addition, $-\mathrm{C}-\mathrm{O},-\mathrm{C}-\mathrm{C}$, and $-\mathrm{C}-\mathrm{OH}$ stretching vibrations could be found at the adsorption peaks of the $1,250-1,000 \mathrm{~cm}^{-1}$ region $[22,25]$. The strong bands at wavenumbers 3,$282 ; 1,634 ; 1,538$; and $1,242 \mathrm{~cm}^{-1}$ could be also corresponding to the amide I-III bands of polypeptide or proteins, respectively [26]. The insignificantly deformations in the region $900-500 \mathrm{~cm}^{-1}$ could be attributed to $-\mathrm{P}-\mathrm{O}$, and aromatic $-\mathrm{CH}$ stretching vibrations $[22,25]$. 


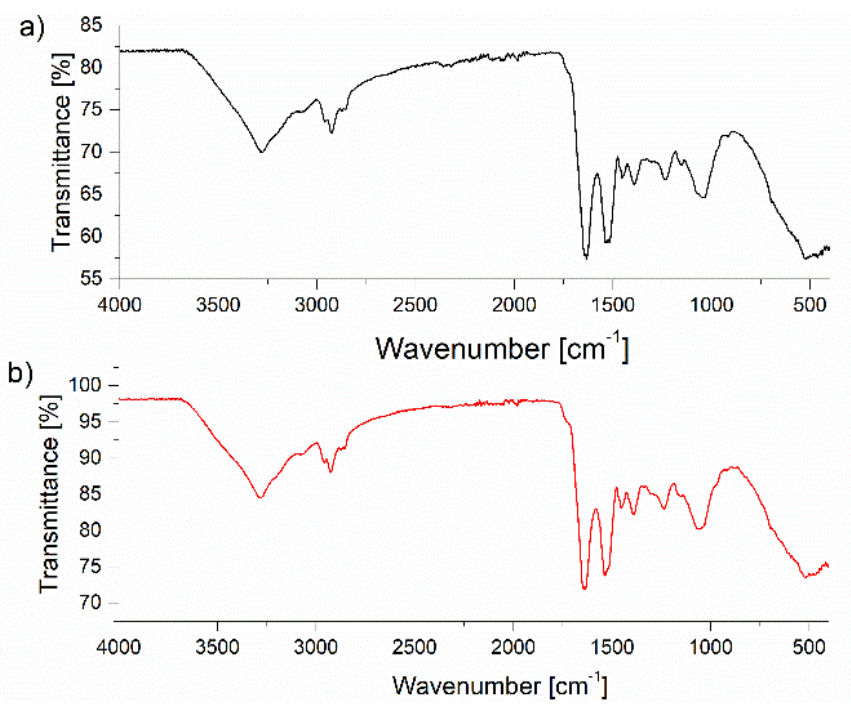

Fig. 6. FT-IR spectra of A. platensis biomass: a) control and b) Li-loaded

The IR spectrum of the Li-loaded spirulina biomass revealed that the hydroxyl (3,278 and 1,633 $\left.\mathrm{cm}^{-1}\right)$, amine $\left(3,278 \mathrm{~cm}^{-1}\right)$, carboxyl $\left(1,750-1,300\right.$ and 1,250-1,000 $\left.\mathrm{cm}^{-1}\right)$, and phosphate (900-500 $\mathrm{cm}^{-1}$ ) functional groups were slightly shifted in comparison with their positions showed on Figure 6. It was caused by Li ions binding to above mentioned groups. In Yun and Volensky study [27] was shown that carboxyl and phosphate groups play important role in lithium ions binding.

Ion-exchange can be considered as another mechanism of lithium biosorption. Since lithium belongs to the group of alkali metals together with sodium and potassium, it can replace these elements due to similar structures [28].

\section{Conclusion}

The potential of Arthrospira platensis biomass application for lithium ions removal from both batch solutions was evaluated. The maximum biosorption capacity of lithium $1.75 \mathrm{mg} / \mathrm{g}$ was achieved at $\mathrm{pH}=11.0$ and sorbent dosage $10 \mathrm{~g} / \mathrm{dm}^{3}$. The equilibrium data were well fitted by Langmuir adsorption isotherm model $\left(R^{2}=0.99\right)$, while the pseudo-second order kinetic model $\left(\mathrm{R}^{2}>0.99\right)$ was found to describe better the kinetic data. The FTIR analysis showed that $\mathrm{OH},-\mathrm{COOH},-\mathrm{NH},-\mathrm{NH}_{2}$, and $-\mathrm{NH}_{3}$ were mainly involved in lithium ions binding. Thus, metal trapping to functional groups and ion-exchange can be proposed as main mechanism of lithium biosorption by Arthrospira platensis biomass. Obtained results indicated that Arthrospira platensis biomass can be used as a cheap and efficient sorbent for lithium removal from wastewater and wastewater post-treatment.

\section{Acknowledgments}

The authors would like to thank the team of $3 \mathrm{MV}$ Tandetron accelerator of IFIN-HH, coordinated by Dr. Tiberiu Sava (Chief of Department) and Dr. Vasile-Gabriel Mosu. 


\section{References}

[1] Nishihama S, Onishi K, Yoshizuka K. Selective recovery process of lithium from seawater using integrated ion exchange methods. Solvent Extract Ion Exchange. 2011:29(3):421-31. DOI: $10.1080 / 07366299.2011 .573435$.

[2] Tsuruta T. Removal and recovery of lithium using various microorganisms. J Biosci Bioeng. 2005;100:562-566. DOI: 10.1263/jbb.100.562.

[3] Marcinčáková R, Kaduková J, Mražíkov A, Velgosová O, Luptáková A, Ubaldini S. Metal bioleaching from spent lithium-ion batteries using acidophilic bacterial strains. Inz Miner. 2016;17:117-20. Available from: https://pdfs.semanticscholar.org/0914/a95011769ec02eb2a2ad50f8a55a389c2814.pdf

[4] Wang L, Meng CG, Ma W. Study on $\mathrm{Li}^{+}$uptake by lithium ion-sieve via the $\mathrm{pH}$ technique. Colloid Surf A. 2009;334:34-9. DOI: 10.1016/j.colsurfa.2008.09.050.

[5] Kurniawan A, Yamamoto T. Biosorption of lithium using biofilm matrix of natural microbial consortium. Microbiol Indonesia. 2015;9(3). DOI: 10.5454/mi.9.3.2.

[6] Aneja RK, Chaudhary G, Ahluwalia SS, Goyal D. Indian. Biosorption of $\mathrm{Pb}^{2+}$ and $\mathrm{Zn}^{2+}$ by non-living biomass of Spirulina sp. J Microbiol. 2010:50:438-42. DOI: 10.1007/s12088-011-0091-8.

[7] Rodrigues MS, Ferreira LS, de Carvalho JC, Lodi A, Finocchio E, Converti AJ. Metal biosorption onto dry biomass of Arthrospira (Spirulina) platensis and Chlorella vulgaris: multi-metal systems. Hazard Mater. 2012;30:217-218. DOI: 10.1016/j.jhazmat.2012.03.022.

[8] Solisio C, Lodi A, Soletto D, Converti A. Cadmium biosorption on Spirulina platensis biomass. Bioresour Technol. 2008:99:5933-7. DOI: 10.1016/j.biortech.2007.11.002.

[9] Finocchio E, Lodi A, Solisio C, Converti A. Chromium(VI) removal by methylated biomass of Spirulina platensis: The effect of methylation process. Chem Eng J. 2010:156:264-9. DOI: 10.1016/j.cej.2009.10.015.

[10] Zinicovscaia I, Yushin N, Shvetsova M, Frontasyeva M. Zinc removal from model solution and wastewater by Arthrospira (Spirulina) platensis biomass. Int $\mathbf{J}$ Phytoremediat. 2018;20:901-8. DOI: 10.1080/15226514.2018.1448358.

[11] Zinicovscaia I, Yushin N, Gundorina S, Demčák Š, Frontasyeva M, Kamanina I. Biosorption of nickel from model solutions and electroplating industrial effluent using cyanobacterium Arthrospira platensis. Desalin Water Treat. 2018;120:158-65. DOI: 10.5004/dwt.2018.22691.

[12] Cepoi L, Zinicovscaia I, Rudi L, Chiriac T, Miscu V, Djur S, et al. Growth and heavy metals accumulation by Spirulina platensis biomass from multicomponent copper containing synthetic effluents during repeated cultivation cycles. Ecol Eng. 2020;142:105637. DOI: 10.1016/j.ecoleng.2019.105637.

[13] Zinicovscaia I, Safonov A, Ostalkevich S, Gundorina S, Nekhoroshkov P, Grozdov D. Metal ions removal from different type of industrial effluents using Spirulina platensis biomass. Int J Phytoremediat. 2019;21(14):1442-8, DOI: 10.1080/15226514.2019.1633264

[14] Cepoi L, Zinicovscaia I, Chiriac T, Rudi L, Yushin N, Miscu V. Silver and gold ions recovery from batch systems using Spirulina platensis biomass. Ecol Chem Eng S. 2019;26(2):229-40. DOI: 10.1515/eces-2019-0029

[15] Gomez S, Garcia A, Landete-Castillejos T, Gallego L, Pantelica D, Pantelica A. Potential of the Bucharest 3MV Tandetron ${ }^{\mathrm{TM}}$ for IBA studies of deer antler mineralization. Nuclear Instruments Methods Phys Res Sect B: Beam Interactions Mater Atoms. 2016;371:413-8. DOI: 10.1016/j.nimb.2015.10.012.

[16] Park J, Sato H, Nishihama S, Yoshizuka K. Lithium recovery from geothermal water by combined adsorption methods. Solvent Extract Ion Exchange. 2012;30:398-404. DOI: 10.1080/07366299.2012.687165.

[17] Zinicovscaia I, Cepoi L, Chiriac T, Mitina T, Grozdov D, Yushin N, et al. Application of Arthrospira (Spirulina) platensis biomass for silver removal from aqueous solutions. Int $\mathrm{J}$ Phytoremediat. 2017;19:1053-8. DOI: 10.1080/15226514.2017.1319332.

[18] Ho YS, McKay G. Pseudo-second order model for sorption processes. Process Biochem. 1999;34:451-65. DOI: 10.1016/S0032-9592(98)00112-5.

[19] Robati D. Pseudo-second-order kinetic equations for modeling adsorption systems for removal of lead ions using multi-walled carbon nanotube. J Nanostruct Chem. 2013;3:55. DOI: 10.1186/2193-8865-3-55.

[20] Ho YS, Huang CT, Huang HW. Equilibrium sorption isotherm for metal ions on tree fern. Process Biochem. 2002;37:1421-30. DOI: 10.1016/S0032-9592(02)00036-5.

[21] Bhatnagar A, Minocha AK, Sillanpää M. Adsorptive removal of cobalt from aqueous solution by utilizing lemon peel as biosorbent. Biochem Eng J. 2010;48:181-6. DOI: 10.1016/j.bej.2009.10.005.

[22] Sud D, Mahajan G, Kaur MP. Agricultural waste material as potential adsorbent for sequestering heavy metal ions from aqueous solutions - a review. Bioresour Technol. 2008;99:6017-27. DOI: 10.1016/j.biortech.2007.11.064. 
[23] Celekli A, Yavuzatmaca M, Bozkurt H. Kinetic and equilibrium studies on biosorption of reactive red 120 from aqueous solution on Spirogyra majuscula. Chem Eng J. 2009;152:139-45. DOI: 10.1016/j.cej.2009.04.016.

[24] Vilar VJ, Botelho CM, Pinheiro JP, Domingos RF, Boaventura RA. Copper removal by algal biomass: biosorbents characterization and equilibrium modelling. J Hazard Mater. 2009;163:1113-22. DOI: 10.1016/j.jhazmat.2008.07.083.

[25] Al-Rub FA, El-Naas MH, Ashour I, Al-Marzouqi M. Biosorption of copper on Chlorella vulgaris from single, binary and ternary metal aqueous solutions. Process Biochem. 2006;41:457-64. DOI: 10.1016/j.procbio.2005.07.018.

[26] Govindaraju K, Basha SK, Kumar VG, Singaravelu G. Silver, gold and bimetallic nanoparticles production using single-cell protein (Spirulina platensis) Geitler. J Mater Sci. 2008;43:5115-22. DOI: 10.1007/s10853-008-2745-4.

[27] Yun YS, Volesky B. Modeling of lithium interference in cadmium biosorption. Environ Sci Technol. 2003;37:3601-8. DOI: 10.1021/es011454e.

[28] Belfiore C, Curia MV, Farías ME. Characterization of Rhodococcus sp. A5wh isolated from a high altitude Andean lake to unravel the survival strategy under lithium stress. Revista Argent Microbiologia. 2018;50(3):311-22. DOI: 10.1016/j.ram.2017.07.005. 